\title{
Agnieszka Szudarek
}

https://orcid.org/0000-0002-6851-9808

Uniwersytet Szczeciński

\section{Kwestia kobieca, transnarodowość i social network. Międzynarodowe zjazdy działaczek organizacji kobiecych do 1914 roku}

Słowa kluczowe: kwesta kobieca na przełomie XIX i XX w., międzynarodowy ruch kobiecy, międzynarodowe kongresy kobiet, działaczki kobiece

\section{Streszczenie}

Celem artykułu jest ukazanie międzynarodowych kongresów działaczek organizacji kobiecych jako narzędzi w komunikacji międzynarodowej, a także jako wydarzeń kluczowych dla poszerzania transnarodowej sieci kontaktów między aktywistkami i budowania kanałów transferu treści programowych ruchu kobiecego do narodowych przestrzeni dyskursu na temat kwestii kobiecej. Kongresy były wyrazem dojrzałości środowiska aktywistek. Nadanie im charakteru międzynarodowego w 1878 r. miało służyć ukazaniu kwestii kobiecej jako istotnego problemu wymagającego rozwiązania. Początkowo taki charakter miały tylko z nazwy. Dopiero te, które współorganizowała założona w 1888 r. Międzynarodowa Rada Kobiet w rzeczywistości zbierały działaczki z szeregu państw należących co zachodnioeuropejskiego kręgu cywilizacyjnego. Sprzyjała temu nie tylko organizacja Rady oparta na kryterium narodowym (państwowym), ale także jej umiarkowany program. Transferowany poprzez prasę, osobiste kontakty, publikacje, korespondencję czy wykłady uczestniczek zjazdów mobilizował lokalne działaczki, wskazywał kierunki i formy aktywności.

\section{Wprowadzenie}

Doświadczenie niedopasowania zadań i ról kobiet do realiów nowego społeczeństwa industrialnego wyłoniło w II połowie XIX w. kwestię kobiecą przede wszystkim jako problem socjalny i ekonomiczny występujący w całej cywilizacji Zachodu. Doświadczenie to, chociaż w różnym zakresie 
i z przesunięciami chronologicznymi było wspólne dla kobiet z różnych środowisk społecznych. Stanęły one przed koniecznością uczestnictwa w rodzącej się gospodarce kapitalistycznej. Wyzwaniem były także procesy demokratyzacji, a zwłaszcza kwestionowanie podmiotowości kobiet i tym samym ich udziału w kształtującym się społeczeństwie obywatelskim. Początkowo niedostrzegana i ignorowana przez elity intelektualne i polityczne kwestia kobieca stała się tematem wielowątkowej debaty publicystycznej. Głos w niej zabierały wywodzące się zazwyczaj z mieszczaństwa aktywistki rodzącego się i krzepnącego na przełomie XIX i XX w. ruchu kobiecego oraz związanych z nim organizacji, ale przede wszystkim intelektualiści, politycy, reformatorzy społeczni, przedstawiciele i przedstawicielki świata literackiego. Dyskusje miały przynieść odpowiedź na pytanie o rolę kobiet w nowoczesnym społeczeństwie, zarówno robotnic, jak i tych ze średnich i wyższych warstw społecznych. Zróżnicowanie debaty i proponowanych rozwiązań ujawniło niejednolite poglądy na ten temat samych aktywistek ${ }^{1}$.

\section{Rozwinięcie}

W ruchu kobiecym rozwinęło się kilka nurtów, które w centrum stawiały interesy odmiennych warstw społecznych, odwoływały się do różnych tradycji światopoglądowych, a w konsekwencji na szczycie hierarchii swoich celów umieszczały inne postulaty. Wpływ na zakres i strategie ich działania miały również warunki społeczno-gospodarcze i ustrojowo-polityczne, odmienne przecież w państwach znajdujących się na różnych etapach uprzemysłowienia i procesu demokratyzacji. Nie bez znaczenia był również - tak jak w przypadku ziem polskich - brak własnej państwowości, stawiający przed działaczkami dodatkowe, wymagające odpowiedzi pytanie jak pogodzić kwestię kobiecą $\mathrm{z}$ dążeniami niepodległościowymi. Niezależnie jednak od zasygnalizowanych różnic w poglądach na temat roli i pozycji kobiet w społeczeństwie, działaczki łączyła świadomość istnienia jednej sprawy kobiecej i konieczności zmian w relacjach między obiema płciami. Ta wspólnota celów doprowadziła w drugiej połowie XIX w. do instytucjonalizacji kontaktów między aktywistkami poprzez międzynarodowe kongresy działaczek ruchu kobiecego. Celem pracy jest określenie, w jaki sposób wpłynęły one na rozwój transnarodowej współpracy akty-

Por. R. Blobaum, „Kwestia kobieca” w Królestwie Polskim (1900-1914), [w:] A. Janiak-Jasińska, K. Sierakowska, A. Szwarc (red.), Działaczki społeczne, feministki, obywatelki. Samoorganizowanie się kobiet na ziemiach polskich do 1918 roku (na tle porównawczym), Wydawnictwo Neriton, Warszawa 2008, s. 37-56. 
wistek oraz formowanie się kanałów komunikacyjnych umożliwiających transferowanie treści programowych ruchu kobiecego do narodowych przestrzeni dyskursu dotyczącego kwestii kobiecej, a co za tym idzie, określenie roli kongresów w petryfikacji przekonania o istnieniu jednej, ponadnarodowej kwestii kobiecej.

Wyniki badań Bonnie S. Anderson wskazują, że instytucjonalizację ruchu kobiecego na poziomie międzynarodowym poprzedzały, uchwytne źródłowo już w połowie XIX w., kontakty między aktywistkami francuskimi, niemieckimi, włoskimi, węgierskimi, a przede wszystkim amerykańskimi i brytyjskimi, wśród których były m.in. Harriet Taylor Mill, Louise Otto-Peters, Elizabeth Cady Stanton, Susan B. Anthony, czy Eugénie Niboyet $^{2}$. Stworzyły one wspólnotę mającą charakter transnarodowy. Budowały ją bowiem relacje, powiązania i procesy wymiany odbywające się między nimi w oderwaniu od terytorium, czy formalnych kontaktów wynikających z istnienia struktur państwowych lub instytucjonalnych, które uważane są $\mathrm{z}$ kolei za istotę relacji określanych w dyskursie naukowym mianem międzynarodowych ${ }^{3}$. Cechą tej sieci społecznej (social network), której uczestniczki stworzyły transgraniczną przestrzeń komunikacyjną było również wytworzenie tożsamości zbiorowej opierającej się na uznaniu tych samych idei, praktyk, wartości i poglądów. Spowodowało to w konsekwencji krystalizowanie się w jej wnętrzu mniej lub bardziej formalnych struktur i sieci powiązań, a wraz z nimi transgranicznych kanałów komunikacyjnych, które umożliwiały transfer myśli leżących u podstaw wyobrażonej idei przynależności, takich jak kontakty korespondencyjne, wizyty, wykłady gościnne, czy publikacje w obcych periodykach współpracujących z zaprzyjaźnionymi działaczkami ${ }^{4}$.

2 W gronie tym znajdowała się także Ernestine Rose, urodzona w 1810 r. na ziemiach polskich (Piotrków Trybunalski) Żydówka, która przez Berlin, Paryż i Londyn dotarła do Nowego Jorku i w połowie XIX w. była aktywną działaczką amerykańskiego ruchu na rzecz praw kobiet. B.S. Anderson, Joyous Greetings: The First International Women's Movement, 1830-1860, University Press, Oxford 2000, s. 4-6, 20-21.

3 H. Kaelble, M. Kirsch, A. Schmidt-Gernig, Zur Entwicklung transnationaler Öffentlichkeiten und Identitäten im 20. Jahrhundert. Eine Einleitung, [w:] H. Kaelble, M. Kirsch, A. Schmidt-Gernig (red.), Transnationale Öffentlichkeiten und Identitäten im 20. Jahrhundert, Campus Verlag, Frankfurt - New York 2002, s. 8-10.

4 Zob. szerzej: S. Zimmermann, Frauenbewegungen, Transfer und Trans-Nationalität. Feministisches Denken und Streben im globalen und zentralosteuropäischen Kontext des 19. und frühen 20. Jahrhunderts, [w:] H. Kaelble, M. Kirsch, A. Schmidt-Gernig (red.), Transnationale Öffentlichkeiten und Identitäten im 20. Jahrhundert, Campus Verlag, Frankfurt - New York 2002, s. 263-302; H. Kaelble, M. Kirsch, 
Podejście transnarodowe $\mathrm{w}$ debacie naukowej zafunkcjonowało w latach 60. XX w. w kontekście badań nad globalizacją i stało się perspektywą analityczną dla szeregu procesów politycznych, społecznych i gospodarczych, w tym także historycznych, które zachodziły w tym samym czasie, ale na różnych terytoriach. W XIX w. taki charakter miały m.in. industrializacja, demokratyzacja, kwestia robotnicza oraz kwestia kobieca. W odniesieniu do nich zamykanie analiz w granicach państw zawęża pole dociekań i nie pozwala dostrzec szeregu uwarunkowań widocznych dopiero w szerszym ujęciu. Transnarodowość łączy się bowiem z wielostronnymi porównaniami, wzajemnymi interakcjami, złożonymi procesami wymiany, które stwarzają niezbędny kontekst do interpretacji i oceny tego co narodowe lub lokalne, także w badaniach nad ruchami kobiecymi ${ }^{5}$. Z tej perspektywy kongresy działaczek jawią się jako wydarzenia umożliwiające podtrzymanie i petryfikacje relacji między aktywistkami oraz stwarzające okazję do rozbudowy sieci transnarodowych kontaktów, a poprzez nie upowszechniania na poziomie narodowym treści będących przedmiotem międzynarodowej (bo zinstytucjonalizowanej w formule kongresu) debaty. Należy je więc uznać za wyraz procesu dojrzewania zidentyfikowanej przez B. Anderson i ewoluującej ponadnarodowej wspólnoty działaczek skupiających się w drugiej połowie XIX w. coraz częściej wokół narodowych (lokalnych) organizacji i periodyków kobiecych ${ }^{6}$. Dojrzewanie to rodziło potrzebę uregulowania komunikacji oraz stworzenia dodatkowych kanałów przepływu informacji ponad granicami państw, służących integracji, wymianie doświadczeń oraz wypracowywaniu programu działania implementowanego następnie do działalności stowarzyszeń kobiecych na poziomie narodowym. Taką rolę kongresy zaczęły jednak odgrywać dopiero od

A. Schmidt-Gernig, Zur Entwicklung..., s. 22; J. Sangster, Crossing Boundaries: Women's Organizing in Europe and the Americas, 1880s-1940s, [w:] P. Jonsson, S. Neunsinger, J. Sangster (red.), Crossing Boundaries: Women's Organizing in Europe and the Americas, 1880s-1940s, Uppsala Universitet, Uppsala 2007, s. 14; M. Gehring, Vorbild, Inspiration oder Abgrenzung? Die Amerikarezeption in der deutschen Frauenbewegug im 19 Jahrhundert, Campus Verlag, Frankfurt - New York 2020, s. 16.

O. Janz, D. Schönpflug, Introduction, [w:] O. Janz, D. Schönpflug (red.), Gender History in a Transnational Perspective: Networks, Biographies, Gender Orders, Berghahn Books, New York - Oxford 2014, s. 2.

$6 \quad$ Por. S. Schötz, Jenseits von Grenzen. Transnationale Kommunikation und transnationale Akteutinnen im Umfeld des Allgemeinen Deutschen Frauenvereins, [w:] E. Schöck-Quinteros, A. Schüler, A. Wilmers, K. Wolff (red.), Politische Netzwerkerinnen. Internationale Zusammenarbeit von Frauen 1830-1960, Trafo Verlag, Berlin 2017, s. 79-101. 
końca lat. 90. XIX w., tj. od czasu skrystalizowania się formuły zjazdów działaczek organizowanych pod auspicjami Międzynarodowej Rady Kobiet (International Council of Women, ICW) (zob. tabela 1).

\section{Tabela 1. Międzynarodowe (ogólne) kongresy działaczek organizacji kobie- cych latach 1878-1914}

\begin{tabular}{|c|c|c|c|}
\hline Lp. & Data & Miejsce & Nazwa \\
\hline 1. & 1878, 25 lipca-7 sierpnia & Paryż & Congrès International du Droit des Femmes \\
\hline 2. & 1888, 25 marca-1 kwietnia & Waszyngton & $\begin{array}{l}\text { Konferencja przygotowawcza International } \\
\text { Council of Women }\end{array}$ \\
\hline 3. & $1889,25-29$ czerwca & Paryż & $\begin{array}{l}\text { Congrès Français et International du Droit } \\
\text { des Femmes }\end{array}$ \\
\hline 4. & 1889, 12-18 lipca & Paryż & $\begin{array}{l}\text { Congrès International des Oeuvres et Institu- } \\
\text { tions Féminines }\end{array}$ \\
\hline 5. & 1892, 13-18 maja & Paryż & Congrès Général des Sociétés Féministes \\
\hline 6. & $1893,15-22$ maja & Chicago & World's Congress of Representative Women \\
\hline 7. & 1896, 8-12 kwietnia & Paryż & Congrès Féministe International \\
\hline 8. & 1896, 19-26 września & Berlin & $\begin{array}{l}\text { Internationaler Kongress für Frauenwerke } \\
\text { und Frauenbestrebungen }\end{array}$ \\
\hline 9. & 1897, 4-7 sierpnia & Bruksela & Congrès Féministe International \\
\hline 10. & 1899, 26 czerwca-5 lipca & Londyn & $\begin{array}{l}\text { International Congress of Women (wraz } \\
\mathrm{z} \text { zebraniem ICW) }\end{array}$ \\
\hline 11. & $1900,18-23$ czerwca & Paryż & $\begin{array}{l}\text { Congrès International des Oeuvres et Institu- } \\
\text { tions Féminines }\end{array}$ \\
\hline 12. & 1900, 5-8 września & Paryż & $\begin{array}{l}\text { Congrès International de la Condition et des } \\
\text { Droits des Femmes }\end{array}$ \\
\hline 13. & $1904,12-18$ czerwca & Berlin & $\begin{array}{l}\text { Der Internationale Frauen-Kongress (wraz } \\
\text { z zebraniem ICW) }\end{array}$ \\
\hline 14. & 1909, 24-30 czerwca & Toronto & $\begin{array}{l}\text { International Congress of Women (wraz } \\
\mathrm{z} \text { zebraniem ICW) }\end{array}$ \\
\hline 15. & 1912, 28-30 kwietnia & Bruksela & Congrès Féministe International \\
\hline 16. & 1913,2-10 czerwca & Paryż & $\begin{array}{l}\text { Dixième Congrès International des Femmes; } \\
\text { Oeuvres et Institutions Féminines, Droits } \\
\text { des Femmes }\end{array}$ \\
\hline 17. & 1914, 16-23 maja & Rzym & $\begin{array}{l}\text { International Congress of Women (wraz } \\
\mathrm{z} \text { zebraniem ICW) }\end{array}$ \\
\hline
\end{tabular}

Źródło: U. Wikander, Some „Kept the Flag”..., s. 55-56.

Do 1914 r., który stanowi bardziej polityczną niż merytoryczną cezurę w badaniach nad ruchami kobiecymi, kongresy aktywistek zwoływane były albo przez organizacje kobiece (krajowe, bądź międzynarodowe), albo 
też indywidualnie, przez zwolenniczki i zwolenników poprawy sytuacji kobiet. Stanowiły samodzielne wydarzenia lub były jednym $\mathrm{z}$ wielu towarzyszących wystawom światowym, organizowanym co kilka lat w stolicach państw zachodniego kręgu cywilizacyjnego rywalizujących ze sobą o przywództwo i wiodącą rolę w postępie naukowo-cywilizacyjnym. Mogły mieć charakter oficjalny lub też prywatny (wykluczający udział publiczności), jak również różnić się podejściem programowym do rozwiązania kwestii kobiecej (kongresy umiarkowanych działaczek mieszczańskich, kongresy działaczek radykalnych, od lat. 90. XIX określane mianem feministycznych, czy kongresy socjalistek). Mogły wreszcie dotyczyć różnych kwestii podejmowanych w ramach dyskusji nad poprawą sytuacji kobiet (kongresy ogólne) lub też jednej, tak jak np. kongresy skupiające się na walce o prawa wyborcze kobiet lub też kongresy organizowane przez ruchy reformy społecznej, czy odnowy moralnej, tak jak np. kongresy zainicjowanego przez Josephine Butler w połowie lat. 70. XIX w. ruchu abolicjonistycznego.

Ten typ aktywności kobiet $\mathrm{w}$ sferze publicznej wpisuje się $\mathrm{w}$ widoczną na przełomie XIX i XX w. modę na kongresy, które organizowane były przez przedstawicieli różnych nauk i orędowników ruchów społeczno-politycznych dążących w czasach przyspieszonego postępu cywilizacyjnego do wymiany doświadczeń, wyników badań czy przeprowadzenia niezbędnych reform społecznych. Pierwszy Międzynarodowy Kongres Praw Kobiet (Congrès International des Droits des Femmes) przygotowany został przez dziennikarza i wolnomyśliciela Leona Richera oraz aktywistkę Marię Deraismes. Odbył się w czasie trzeciej wystawy światowej w Paryżu, między 25 lipca a 8 sierpnia 1878 r. Miał zwrócić uwagę elit intelektualno-politycznych na konieczność rozszerzenia praw obywatelskich kobiet we Francji, gdyż ruch kobiecy nad Sekwaną rodził się w ścisłych związkach z działalnością zwolenników republiki i socjalizmu utopijnego ${ }^{7}$. Mimo iż w programie kongresu nie uwzględniono dyskusji nad równouprawnieniem politycznym obu płci, to jednak znalazły się w nim inne kontrowersyjne zagadnienia, takie jak m.in. walka $\mathrm{z}$ reglamentowaną przez państwo prostytucją oraz podwójnymi standardami moralnymi kobiet i mężczyzn, czy postulat takiego samego wynagrodzenia dla obu płci za tę samą pracę. Organizatorzy wystawy uznali więc program kongresu za radykalny i odmówili oficjalnego włączenia zjazdu do wydarzeń towarzyszących wystawie. Mimo to odbył się on, ale jako prywatny, a więc niedostępny dla publiczności. Co prawda wzbudził zainteresowanie mieszkańców i prasy, ale nie przyniósł oczekiwanych rezultatów, gdyż francuskie elity nie były

L. Klejman, Les Congrès féministes internationaux, „Mil neuf cent: Revue d'histoire intellectuelle (ex-Cahiers Georges Sorel)” 1989, nr 7, s. 74-75. 
zainteresowane debatą o prawach kobiet. Stał się jednak wzorem dla kolejnych tego typu przedsięwzięć, które miały miejsce podczas następnych paryskich wystaw w 1889 i 1900 r. Wówczas to jednak udało się zorganizować kongresy oficjalne, cieszące się poparciem francuskiego rządu. Ceną za to było skupienie się podczas obrad na nie budzących kontrowersji formach aktywności kobiet związanych głównie z pracą filantropijną (Congrès International des Oeuvres et Institutions Féminines). Nie satysfakcjonowało to oczywiście radykalnych działaczek i niemal w tym samym czasie zarówno w 1889, jak i w 1900 r. odbyły się również niedostępne dla publiczności kongresy debatujące nad prawami obywatelskimi kobiet (Congrès Français International du Droit des Femmes). Ten dualizm ukazywał wyraźnie, że państwo nie było zainteresowane przedefiniowaniem zadań kobiet, jednak zwolenniczki i zwolennicy równych praw kobiet i mężczyzn we Francji próbowali negocjować z elitami rządzącymi co do zakresu, w jakim te ostatnie są gotowe zmienić swoje stanowisko. Mimo upływu czasu skala ustępstw była niewielka, zwłaszcza że francuska opinia publiczna wciąż była niechętna emancypacji kobiet, a na łamach paryskiej prasy nie brakowało drwin i złośliwych komentarzy na ten temat ${ }^{8}$. Z podobnymi trudnościami nie spotkali się natomiast organizatorzy kongresów kobiet odbywających się przy okazji wystaw światowych w Chicago (World's Congress of Representative Women), w 1893 r. i w Brukseli (Congrès Féministe International), w 1897 r. Ich programy nie pomijały kwestii równościowych, zaś kongres brukselski był pierwszym towarzyszącym wystawie, który nazwany został feministycznym?.

Drugą grupę międzynarodowych kongresów kobiet stanowiły te, które organizowane były okazjonalnie przez różne stowarzyszenia lub aktywistki. Do tej kategorii należały dwa kongresy, które miały miejsce w stolicy Francji w 1892 (Congrès Général des Sociétés Féministes) ${ }^{10}$ i w 1896 r.

$8 \quad$ K. Offen, Debating the Woman Question in the French Third Republic, 1879-1920, University Press, Cambridge 2018, s. 134-146; A. Rasmussen, Les Congrès internationaux liés aux Expositions universelles de Paris (1867-1900), „Mil neuf cent: Revue d'histoire intellectuelle (ex-Cahiers Georges Sorel)" 1989, nr 7, s. 25-32; K.L. Kern, "The Cornerstone of a New Civilization”. The First International Council of Women and the Campaign for „Social Purity”, „Kentucky Law Journal” 1996, t. 84, nr 4, s. 1237.

$9 \quad$ U. Wikander, Equality Claimed: Women’s Congresses in Paris 1892 \& 1896, s. 1, http:// www.ullawikander.se/wp-content/uploads/2017/04/Chapter-6-Pdf.pdf [dostęp: 25.08.2020]

10 Kongres zorganizowały Fédération Française des Sociétés Féministes oraz stowarzyszenie Marii Szeligi Union Universelle des Femmes. K. Offen, Debating the Woman Question..., s. 159-161. 
(Congrès Féministe International) oraz przygotowany w 1912 r. w Brukseli przez organizację La Ligue Belge du Droit des Femmes z okazji dwudziestej rocznicy jej powstania Congrès Féministe International ${ }^{11}$. Miały one charakter radykalny i określane były przez same działaczki jako feministyczne. Przymiotnik "feministyczny” trafił do ponadnarodowego dyskursu na temat kwestii kobiecej z Francji, upowszechniając się ok. 1890 r. m.in. za sprawą Marii Szeligi (Chéliga-Loévy), Polki mieszkającej i działającej nad Sekwaną. W 1891 r. został użyty w nazwie powstałego w Paryżu zrzeszenia francuskich stowarzyszeń kobiecych (Fédération Française des Sociétés Féministes). W tym czasie też zwolenniczki równouprawnienia płci zaczęły określać się feministkami ${ }^{12}$. Hasłami równościowymi nie szermował natomiast kongres, który z inicjatywy Liny Morgenstern odbył się w Berlinie, w 1896 r., gdyż jego celem było zwrócenie uwagi niemieckiej opinii publicznej na kwestię kobiecą (Internationaler Kongress für Frauenwerke und Frauenbestrebungen ${ }^{13}$.

Kongresy z końca XIX w. międzynarodowymi były jednak tylko z nazwy. Zarówno zjazd berliński, z 1896 r., jak i kongresy paryskie gromadziły przede wszystkim miejscowe działaczki. Dla przykładu do Paryża, w 1878 r. zjechało się 220 osób z jedenastu różnych państw, jednak sama delegacja francuska liczyła 168 osób, w większości mężczyzn. Drugi paryski kongres praw kobiet zebrał z kolei 200 uczestników, wśród których tylko 17 było obcokrajowcami, co jednak w dużej mierze wynikało z prywatnego charakteru zjazdu i wysokich cen biletów wstępu na obrady. W Chicago w 1893 r. dominowały natomiast Amerykanki. Dopiero kongresy organizowane przy udziale Międzynarodowej Rady Kobiet miały rzeczywiście

11 Zorganizowała go Eugénie Potonié-Pierre we współpracy z Marią Martin. U. Wikander, Equality Claimed: Women's Congresses in Paris 1892 \& 1896, s. 10, http:// www.ullawikander.se/wp-content/uploads/2017/04/Chapter-6-Pdf.pdf [dostęp: 25.08.2020]; W.H. Wilkins, The Paris International Feminist Congress of 1896 and its French Antecedents, „North Dakota Quarterly” 1975, nr 4 (Autumn), s. 11-16, 27.

12 U. Wikander, Suffrage and the Labour Market: European Women at International Congresses in London and Berlin, 1899 and 1904, [w:] P. Jonsson, S. Neunsinger, J. Sangster (red.), Crossing Boundaries: Women's Organizing in Europe and the Americas, 1880s-1940s, Uppsala Universitet, Uppsala 2007, s. 22; K. Offen, Debating the Woman Question..., s. 169-170.

13 G. Bäumer, Die Geschichte der Frauenbewegung in Deutschland, [w:] H. Lange, G. Bäumer (red.), Handbuch der Frauenbewegung in den Kulturländern, Berlin 1901, s. 151-152; M. Popelin, Actes du Congrès Féministe International de Bruxelles 1912, 1892-1912, Bruxelles 1912. 
zgodny z nazwą charakter ${ }^{14}$ będąc skutkiem transnarodowych kontaktów między działaczkami z Europy Zachodniej i zza Atlantyku.

Międzynarodowa Rada Kobiet została założona w 1888 r. Nie była jednak pierwszą ponadnarodową organizacją kobiecą, gdyż za takową jest uważane powstałe w 1868 r. w Szwajcarii, z inicjatywy Marie Goegg Association Internationale des Femmes. Stawiało ono sobie za cel zjednoczenie aktywistek m.in. do walki o prawa polityczne dla kobiet i taką samą płacę za taką samą pracę dla obu płci. Do wybuchu wojny francusko-pruskiej jej oddziały zawiązały się na obszarze Niemiec, w Wielkiej Brytanii, Francji, Włoszech, Portugalii i w Stanach Zjednoczonych. Ze względu na radykalizm i wydarzenia polityczne, jak i wewnętrzne podziały na początku lat siedemdziesiątych XIX w. stowarzyszenie zakończyło swoją działalnośćc ${ }^{15}$. Mimo iż funkcjonowało zaledwie kilka lat, ukazało $\mathrm{z}$ jednej strony gotowość aktywistek do współpracy, z drugiej zaś wewnętrzne rozbieżności programowe, ale i niewielkie zainteresowanie opinii publicznej i rządów poprawą sytuacji kobiet. Następne lata przyniosły kolejne próby utworzenia międzynarodowej organizacji kobiecej, podejmowane m.in. przez działaczki znad Sekwany. Tradycje rewolucyjne Francji powodowały, że rościły sobie one prawo do uczynienia Paryża centrum walki o prawa kobiet. Jedną z nich była założona w 1889 r. przy udziale wspomnianej wyżej Marii Szeligi Union Universelle des Femmes ${ }^{16}$. Radykalizm żądań części francuskich aktywistek, jak i zasadniczo całego pierwszego pokolenia mieszczańskich działaczek kobiecych, nie spotykał się - jak już wyżej zasygnalizowano $-\mathrm{z}$ poparciem społecznym, w związku z tym punkt ciężkości działań mających zinstytucjonalizować ruch kobiecy przesunął się do Stanów Zjednoczonych ${ }^{17}$. Za sprawą Elizabeth Cady Stanton i Susan B. Anthony, liderek National American Woman Suffrage Association, które na początku lat 80. XIX w. podczas podróży po Europie nawiązały kontakty z lokalnymi aktywistkami, zrodziła się koncepcja powołania międzynarodowej

$14 \quad$ J. Evans, The Feminists: Women's Emancipation Movements in Europe, America and Australasia 1840-1920, Routledge, London - New York 2013, s. 246-252.

K. Offen, European Feminism 1700-1950. A Political History, University Press, Stanford 2000, s. 150-151; M. Gehring, Vorbild..., s. 107-108; J. Evans, The Feminists..., s. 247-248.

16 K. Offen, European Feminism..., s. 160.

17 Zob. też: J. Carlier, A Forgotten Instance of Women's International Organising. The Transnational Feminist Networks of the Women's Progressive Society (1890) and the International Women's Union (1893-1898), [w:] O. Janz, D. Schönpflug (red.), Gender History in a Transnational Perspective: Networks, Biographies, Gender Orders, Berghahn Books, New York - Oxford 2014 s. 77-100. 
organizacji kobiecej. W marcu 1888 r. amerykańskie sufrażystki zorganizowały w Waszyngtonie obchody upamiętniające konwencję w Seneca Falls z 1848 r. i powołały do życia Międzynarodową Radę Kobiet, która zgodnie ze statutem miała być platformą stałej „komunikacji między stowarzyszeniami z wszystkich krajów” i inicjować „spotkania i dyskusje w sprawach dotyczących dobra publicznego oraz bezpieczeństwa rodziny i jednostki" ${ }^{18}$. Na czele Rady stało wybierane na pięcioletnie kadencje prezydium pod kierownictwem przewodniczącej, zaś odbywającym się co 5 lat jego posiedzeniom towarzyszyły kongresy działaczek kobiecych ${ }^{19}$. Zadania Rady, a także formuła kongresów zostały ustalone w 1893 r. w Chicago. Do 1914 r. odbyły się one: w 1899 r. Londynie, w 1904 r. Berlinie, w 1909 r. w Toronto i w maju 1914 r. w Rzymie ${ }^{20}$. Od 1899 r. Rada zaczęła powoływać również zajmujące się konkretnymi sprawami stałe komitety obradujące między jej posiedzeniami ${ }^{21}$.

Międzynarodowy charakter tych kongresów wynikał z organizacji ICW, która skupiała Narodowe Rady Kobiet (National Councils of Women), czyli zrzeszenia stowarzyszeń kobiecych z poszczególnych państw. Pierwsze tego typu zrzeszenie powstało w Stanach Zjednoczonych, kolejne na prze-

18 W preambule statutu zapisano: „We, women of all Nations, sincerely believing that the best good of humanity will be advanced by greater unity of thought, sympathy, and purpose, and that an organised movement of women will best conserve the highest good of the family and of the State, do hereby band ourselves in a confederation of workers to further the application of the Golden Rule to society, custom, and law" [The Golden Rule. - „Do unto others as ye would that they should do unto you”]. Report on the quinquennial meetings. Rapport de l'assemblée quinquennal. Bericht über die Generalversammlung, Rome 1914, s. 483; K. Offen, European Feminism..., s. 154, 157; L.J. Rupp, Worlds of Women: The Making of an International Women's Movement, Princeton University Press, Princeton 1997, s. 15 i nast.; Ch. Klausmann, R. Schäfer, E. Schüller, U. Wischermann, Internationale Kongresse der alten und neuen Frauenbewegung, „Feministische Studien” 1994, nr 2, s. 100.

W 1908 r. Rada zebrała się w Genewie na posiedzeniu nadzwyczajnym w celu zatwierdzenia zmiany w statucie. O. Gordon, The Formation and Growth of the International Council of Women, [w:] Agenda for the Quinquennial Sessions of the International Council of Women, held at Toronto, Canada, June 1909, 1909, s. 19.

20 International Council of Women. Quinquennial Reunion in Canada 1909, 1910; International Council of Women. Report on the Quinquennial Meetings. Rome 1914.

$21 \quad$ L.J. Rupp, Worlds of Women..., s. 15-19; K. Offen, Overcoming Hierarchies Through Internationalism. May Wright Sewall's Engagement with the International Council of Women (1888-1904), [w:] F. de Haan, M. Allen, J. Purvis, K. Daskalova (red.), Women's Activism. Global Perspectives from the 1890s to the Present, Routledge, London - New York 2013, s. 19-24; U. Wikander, Suffrage and the Labour Market..., s. 21. 
łomie XIX i XX w. w Kanadzie (1893), Niemczech (1894, przyjęte do ICW w 1897 r.), Szwecji (1898), Wielkiej Brytanii (1898), Danii (1899), Holandii (1899), Nowej Zelandii (1900), Argentynie (1901), Francji (1901) i innych państwach. Do 1914 r. zawiązały się 23 Narodowe Rady Kobiet ${ }^{22}$. Wpłynęła na to działalność May Wright Sewall, od 1894 r. wiceprzewodniczącej, a od w latach 1899-1904 przewodniczącej ${ }^{23}$, która inspirowała powoływanie Narodowych Rad Kobiet, stymulując tym samym instytucjonalizację ruchu kobiecego. Trzeba jednak podkreślić, że owo kryterium narodowe w praktyce było kryterium państwowym. W organizmach wielonarodowych takich jak np. Austro-Węgry rodziło to szereg komplikacji, gdyż wymuszało przynależność do jednego zrzeszenia kobiet różnych narodowości, a to właśnie świadomość narodowa stanowiła podstawowy poziom samoorganizacji działeczek ${ }^{24}$. W czasie kongresów działaczki identyfikowano jednak narodowo. Przemawiająca na kongresie w Londynie 1899 r. Salomea Chwatowa w programie odnotowana została jako Polka ${ }^{25}$. Dyskusje nad zmianą tej zasady i akcesami do ICW zrzeszeń reprezentujących nie państwa, a narody dyskutowano w ostatnich latach przed wybuchem wojny. Jednak było to kwestia trudna, gdyż obowiązująca struktura ICW wynikała $\mathrm{z}$ dążeń do wbudowania ruchu kobiecego $\mathrm{w}$ określony porządek prawno-organizacyjny, który miał przede wszystkim legitymizować

22 K.L. Kern, „The Cornerstone..., s. 1236-1237; A. Schüler, K. Wolff, „Es sind die gleichen Überzeugungen, die die Frauen aller Länder erfüllen..." Zur Entstehung von internationalen Netzwerken in den Frauenbewegung, [w:] E. Schöck-Quinteros, A. Schüler, A. Wilmers, K. Wolff (red.), Politische Netzwerkerinnen. Internationale Zusammenarbeit von Frauen 1830-1960, Trafo Verlag, Berlin 2017, s. 17-18.

K. Offen, Understanding International Feminisms as 'Transnational' - an Anachronism? May Wright Sewall and the Creation of the International Council of Women, 1889-1904 [w:] O. Janz, D. Schönpflug (red.), Gender History in a Transnational Perspective: Networks, Biographies, Gender Orders, Berghahn Books, New York-Oxford 2014, s. 31-38; K. Offen, Overcoming Hierarchies Through Internationalism..., s. 15-27.

A. Leszczawski-Schwerk, „Die umkämpfende Tore zur Gleichberechtigung“ - Frauenbewegungen in Galizien (1867-1918), Lit, Münster 2015, s. 51-53; G. Dudeková, Międzynarodowa działalność kobiet w Austro-Węgrzech i VII Kongres Międzynarodowego Stowarzyszenia na Rzecz Praw Wyborczych Kobiet w Budapeszcie w 1913 roku, [w:] A. Janiak-Jasińska, K. Sierakowska, A. Szwarc (red.), Działaczki społeczne, feministki, obywatelki. Samoorganizowanie się kobiet na ziemiach polskich do 1918 roku (na tle porównawczym), Wydawnictwo Neriton, Warszawa 2008, s. 165.

25 Mne de Chwatowa (Poland), The Teaching of the Rudiments of Law in Primary Schools, [w:] the Countess of Aberdeen (red.), The International Congress of Women of 1899: Women in Politics being the Political Section of the International Congress of Women, London, July 1899, London 1900, s. 89-95. 
go w oczach elit rządzących. Stanowiła również narzędzie umożliwiające implementację rezolucji przyjmowanych na zakończenie kongresów. Narodowe Rady Kobiet były bowiem odpowiedzialne za działanie na rzecz ich realizacji w poszczególnych państwach ${ }^{26}$.

Międzynarodowa Rada Kobiet, chociaż została powołana przez sufrażystki, krzepła dystansując się coraz bardziej od radykalnych haseł równościowych (feministycznych), które popierała zdecydowana mniejszość aktywistek kobiecych. Odcinała się też od sporów politycznych i religijnych, podkreślając kobiecą solidarność i deklarując kierowanie się w swojej działalności biblijną tzw. złotą regułą, tj. czyń tak, jak chcesz by tobie czyniono $^{27}$. Ten zwrot podkreślał wybór na przewodniczącą ICW w $1893 \mathrm{r}$. hrabiny Ishbel lady Aberdeen, która dążyła do zbudowania jak najszerszej platformy współpracy między stowarzyszeniami kobiecymi. Pod takim umiarkowanym i arystokratycznym kierownictwem Rada miała również większe szanse na poparcie przez rządy poszczególnych państw, co nie było bez znaczenia w kontekście reform mających poprawić sytuację kobiet ${ }^{28}$. Działaczki dążąc do legitymizacji ruchu, zapraszały osobistości z życia politycznego, kulturalnego do komitetów honorowych poszczególnych kongresów. W 1904 r. kongres berliński swoim patronatem objęła niemiecka cesarzowa. Organizatorkom chodziło o zbudowanie przekonania o słuszności i ważności podejmowanych podczas obrad tematów, zaś rozmach zjazdów i ich bardzo dobre przygotowanie miały ukazać działaczki jako poważne i odpowiedzialne partnerki dla elit rządzących do debaty na temat sytuacji kobiet.

Pozycję Rady w sferze publicznej wzmocniło także odcięcie się od walki o prawa wyborcze dla kobiet, co miało miejsce podczas obrad kongresu londyńskiego w 1899 r. W tej sytuacji sufrażystki zdecydowały się powołać odrębną organizację międzynarodową, która z inicjatywy Susan B. Anthony została nieoficjalnie założona w Waszyngtonie w 1902 r. podczas konferencji przygotowawczej, oficjalnie zaś w 1904 r. w Berlinie jako Międzynarodowy Sojusz na Rzecz Praw Wyborczych Kobiet (International Woman Suffrage Alliance, IWSA) pod przewodnictwem Carrie Chapman $\mathrm{Catt}^{29}$. Zarząd tej organizacji, podobnie jak zarząd ICW zbierał się regular-

\footnotetext{
26 Por. S. Zimmermann, Frauenbewegungen..., s. 263-302.

27 U. Gerhard, National oder International. Die internationalen Beziehungen der deutschen bürgerlichen Frauenbewegung, „Feministische Studien” 1994, nr 2, s. 40. L.J. Rupp, Worlds of Women..., s. 20.

29 J.M., Die Tagung des Weltbunder für Frauentimmrecht, „Frauenbestrebungen. Offizielles Organ der „Union für Frauenbestrebungen“ 1906, 1 Oktober, no 10, s. 73;
} 
nie. Również regularnie, zazwyczaj co dwa lata, odbywały się konferencje, przekształcone później w kongresy przedstawicielek narodowych zrzeszeń wchodzących w skład Sojuszu. Do 1914 r. miały one miejsce: w Kopenhadze w 1906 r., w 1908 r. w Amsterdamie, następnie w 1909 r. w Londynie, w 1911 r. w Sztokholmie oraz w 1913 r. w Budapeszcie ${ }^{30}$. Międzynarodowa Rada Kobiet ostatecznie jednak jeszcze przed wybuchem wojny uznała, że prawa wyborcze są nieodłącznym elementem ruchu kobiecego. Działaczki umiarkowane wywodziły je nie z przekonania o równości płci, ale z przeświadczenia, że to co kobiece, jest tak samo ważne, jak to co męskie. Propagowały podejście komplementarne do relacji między kobietami i mężczyznami, głosząc ich równość w ramach przyporządkowanych im odmiennych zadań. Odmienne, bo definiowane przez paradygmat macierzyński zadania kobiet wymagały jednak włączenia ich do wspólnoty obywatelskiej (zwłaszcza na poziomie samorządowym), a więc także nadania praw politycznych ${ }^{31}$.

Wyłonienie się w środowisku międzynarodowym odrębnej organizacji na rzecz praw wyborczych kobiet wskazuje na dywersyfikację i specjalizację procesu instytucjonalizacji ruchu kobiecego. Kongresy IWSA nie były bowiem jedynymi. Od 1907 r. zaczęły spotykać na własnych zjazdach socjalistki. Swoje struktury budował również wyznaniowy ruch kobiecy. Na płaszczyźnie międzynarodowej integrowały się kobiety reprezentujące określone grupy zawodowe. Organizacje te współpracowały z Międzynarodową Radą Kobiet, która ze względu na swój umiarkowany program wyrosła $\mathrm{w}$ pierwszych latach XX $\mathrm{w}$. na kluczowe zrzeszenie kobiece

L.J. Rupp, Zur Organisationsgeschichte der internationalen Frauenbewegung vor dem Zweiten Weltkrieg, „Feministische Studien” 1994, nr 2, s. 55-57; A. Schüler, K. Wolff, „Es sind die gleichen Überzeugungen..., s. 20.

30 Kolejny kongres zaplanowany był w Berlinie na rok 1915. Ze względu na wybuch wojny nie odbył się, jednak w zamian sufrażystki zebrały się w neutralnej Holandii i zorganizowały tam międzynarodowy kongres pacyfistek (International Women's Peace Congress), który zapoczątkował działalność Międzynarodowej Ligi na rzecz Pokoju u Wolności (Women's International Leage for Peace and Freedom). L.J. Rupp, Worlds of Women..., s. 26-29; S. Kinnebrock, „Wahrhaft international?" Soziale Bewegungen zwischen nationalen Öffentlichkeiten und internationalem Bewegungsverband, [w:] E. Schöck-Quinteros, A. Schüler, A. Wilmers, K. Wolff (red.), Politische Netzwerkerinnen. Internationale Zusammenarbeit von Frauen 1830-1960, Trafo Verlag, Berlin 2017, s. 42-43; G. Dudeková, Międzynarodowa działalność kobiet..., s. 145-169.

31 Zob.: N. Berkovitch, From Motherhood to Citizenship. Women's Rights and International Organizations, The Johns Hopkins University Press, Baltimore-London 1999. 
w środowisku międzynarodowym, a jej kongresy stały się znaczącymi wydarzeniami propagującymi kwestię kobiecą.

Podczas zazwyczaj kilkudniowych obrad kongresów ICW obfitujących w szereg wydarzeń towarzyskich i bankietów, działaczki starały się sprawy kobiet umieścić w szerszym kontekście reform społecznych i dążeń do naprawy moralnej świata. Proponowały wizję lepszego, sprawiedliwszego świata, w którego budowie kobiety miały uczestniczyć na równi z mężczyznami. Widoczne było to m.in. w debacie na temat ustawodawstwa ochronnego dla matek zainspirowanej regulacjami, które w tej sferze wprowadzono m.in. w 1891 r. w Niemczech i w 1892 r. we Francji ${ }^{32}$. Specjalnemu traktowaniu matek sprzeciwiały się aktywistki radykalne stawiające na pierwszym miejscu równość płci także w sferze zatrudnienia ${ }^{33}$. Natomiast lady Aberdeen i inne działaczki Międzynarodowej Rady Kobiet nie ukrywały, że według nich powołaniem kobiet jest przede wszystkim rodzina. Ten swoisty podział pracy stanowił więc odejście od koncepcji równościowych formułowanych przez pierwsze pokolenie aktywistek. Drugie pokolenie działaczek stawiało sobie za cel nie zmianę, ale zmodernizowanie tradycyjnych zadań kobiet, formułując postulaty reform społecznych i równouprawnienia tzw. kultury kobiecej z dominującą we wszystkich sferach życia polityczno-społecznego kulturą mężczyzn. W ramach tego szerokiego programu naprawy społecznej kongresy odbywające się pod auspicjami ICW zajmowały się także statusem prawnym kobiet, ich rolą $\mathrm{w}$ administracji samorządowej, pracą socjalną, jak również walką z prostytucją i handlem kobietami, edukacją, ale rozumianą bardzo szeroko, łącznie z zagadnieniami praktycznymi i moralnymi, począwszy od dyskusji nad szkodliwością karmienia niemowląt przez mamki, poprzez kwestie metod nauczania, po koedukację oraz dostęp kobiet do studiów wyższych ${ }^{34}$. Kongresy nie miały więc wyraźnego programu, ani wypracowanej strategii kształtującej ich obecność w sferze publicznej. Rzadko też debatowały, raczej informowały, starając się podkreślić wagę kwestii kobiecej i pogłębić świadomość społeczną z zakresu problemów kobiet $\mathrm{z}$ różnych warstw społecznych oraz promować propozycje ich rozwiązania w ramach szerszej wizji przebudowy stosunków społecznych. Jednak dopiero w takiej formule, dystansują-

\footnotetext{
32 U. Wikander, Suffrage and the Labour Market..., s. 22-24, 42.

33 Ibidem, s. 26, 28; Eadem, Some „Kept the Flag” of Feminist Demands Waving. Debates at International Congresses on Protecting Women Workers, [w:] U. Wikander, A. Kessler-Harris, J.E. Lewis (red.), Protecting Women. Labor Legislation in Europe, the United States, and Australia, 1880-1920, University of Illinois, Urbana 1995, s. 29-62.

$34 \quad$ K. Offen, Debating the Woman Question..., s. 53-54.
} 
cej się od feministycznego postulatu równości płci, w tym i walki o prawa wyborcze dla kobiet, mogły stać się międzynarodowymi wydarzeniami mającymi szansę rozbudować transnarodową sieć powiązań między działaczkami najliczniejszego, umiarkowanego pod względem programowym ruchu kobiecego. Co więcej, kongresy ICW organizowane przez działające w poszczególnych państwach Narodowe Rady Kobiet nie mogłyby się odbywać bez wykorzystania transnarodowych kontaktów działaczek, które ułatwiały zapraszanie gości, zbieranie informacji, a zwłaszcza propagowanie idei kongresowej, wpływając przy tym na petryfikację i rozbudowę sieci powiązań osobistych. Wykazał to kongres berliński w 1904 r., który jest uważany za manifestację szczytowego punktu zsieciowania działaczek do 1914 r. Dogodne położenie stolicy Niemiec umożliwiło przybycie licznych delegatek z najodleglejszych zakątków świata, m.in. Nowej Zelandii, Tasmanii, Stanów Zjednoczonych, czy Australii, co wymagało zaangażowania w prace organizacyjne komitetu złożonego aż ze 150 kobiet $^{35}$.

Sieci te wspierały także budowę ponadnarodowych kanałów komunikacyjnych wewnątrz wspólnoty ideowej jaką tworzyły działaczki związane lub sympatyzujące z Międzynarodową Radą Kobiet. Obok tradycyjnych kanałów transferu takich jak kręgi korespondencyjne, prasa, podróże wraz wykładami gościnnymi działaczek, wymienić należy nowe. Pierwszym były informatory i publikacje pokongresowe będące zbiorem wygłoszonych referatów i przyjętych rezolucji, nawiązujące formą do esejów zebranych i wydanych w 1884 r. przez Teodora Stantona, syna amerykańskiej sufrażytski Elisabeth Cady Stanton i uczestnika pierwszego paryskiego kongresu w 1878 r. pt. The Woman Question in Europe: A Series of Original Essays. W tym międzynarodowym kompendium, w którym Frances Power Cobbe użyła pierwszy raz metafory fali dla oddania charakteru rozwoju ruchu kobiecego, znalazły się prace nie tylko na temat sytuacji kobiet we Francji, czy Anglii, ale także i w innych, mniejszych państwach, a także tekst Elizy Orzeszkowej dotyczący ziem polskich ${ }^{36}$. Publikacje te miały istotny wymiar informacyjny, służąc działaczkom jako źródła wiedzy m.in. na temat aktów prawnych, wyników badań, czy statystyk, które miały wspierać je w budowaniu argumentacji podczas debat $\mathrm{z}$ przeciwnikami sprawy kobiecej. O wydawanie tych prac szczególnie zabiegała wieloletnia przewodnicząca ICW - lady Aberdeen.

35 A. Schüler, K. Wolff, „Es sind die gleichen Überzeugungen..., s. 14-15, 26.

36 K. Offen, European Feminism..., s. 153-154; E. Oresko, Poland, [w:] T. Stanton (red.), The Woman Question in Europe. A Series of Original Essays, London 1884, s. 425-445. Esej Orzeszkowej został w tej publikacji skrócony. W wersji rozszerzonej ukazał się $\mathrm{w}$ polskim tłumaczeniu tego tomu wydanym w $1885 \mathrm{r}$. 
Drugim nowym kanałem transferu dorobku kongresów była działalność tzw. wędrownych aktywistek, działaczek nowego typu, który zafunkcjonował na przełomie XIX i XX w. dzięki zdobyczom techniki i nowym, zwiększającym mobilność ludzi, środkom transportu. Ich praca polegała na tym, że po zakończeniu obrad kongresowych objeżdżały one $\mathrm{z}$ wykładami ważniejsze miasta w swoim kraju, spotykały się z lokalnymi zwolenniczkami i zwolennikami emancypacji kobiet rozszerzając sieć kontaktów, ale też służąc aktywistkom jako wzorzec do naśladowania. Przykładem może być tu postać pochodzącej z Gdańska działaczki Käthe Schirmacher, a zwłaszcza jej podróże informacyjno-propagandowe po Niemczech po powrocie $\mathrm{z}$ kongresu w Chicago w $1893 \mathrm{r}^{37}$

$\mathrm{Na}$ początku XX w. wzrosła także rola prasy $^{38}$. W periodykach organizacji kobiecych w latach poprzedzających I wojnę światową pojawiały się stałe rubryki z informacjami dotyczącymi międzynarodowego ruchu kobiecego. Dzięki zabiegom aktywistek oraz powołaniu w strukturach ICW Biura Informacyjnego, do redakcji periodyków w różnych krajach rozsyłane były wiadomości dotyczące kongresów wraz z zaproszeniami do udziału. Prasa codzienna odnotowywała je nie tylko jako „ciekawostkę ze świata”, ale publikowała, niekiedy nawet obszerne, sprawozdania z przebiegu obrad, chociaż nie zawsze z pozytywnym komentarzem. Tego typu artykuły ukazywały się także na łamach polskich periodyków, pozwalając śledzić wydarzenia wpisujące się w rozwój międzynarodowego ruchu kobiecego $^{39}$. Cieniem na ocenie kongresów ICW kładła się pamięć o niekiedy chaotycznym przebiegu i radykalnym programie pierwszych paryskich kongresów praw kobiet. Same działaczki były zresztą tego świadome i tym bardziej zabiegały o sprawną organizację swoich zjazdów i jak najszersze poparcie. W ten sposób chciały wpisać kwestię kobiecą do katalogu najistotniejszych, wymagających rozwiązania problemów społecznych.

37 J. Gehmacher, Moderne Frauen, die Neue Welt und der alte Kontinent. Käthe Schirmacher reist im Netzwerk der Frauenbewegung, „Österreichische Zeitschrift für Geschichtswissenschaften” T. 22, 2011, nr 1, s. 16-40; Eadem, Reisende in Sachen Frauenbewegung Käthe Schirmacher zwischen Internationalismus und nationaler Identifikation, „Ariadne. Forum für Frauen- und Geschlechtergeschichte” 2011, t. 60, s. 58-65.

Międzynarodowa Rada Kobiet nie doczekała się własnego periodyku, jakim dla IWSA było pismo „Jus Suffragii” wydawane od 1906 r. 
Ponadnarodowemu transferowi idei sprzyjały również zawiązywane podczas kongresów znajomości i przyjaźnie. Przykładem może być relacja jaka łączyła Niemkę Alice Salomon z Amerykanką Jane Addams, której osią było zainteresowanie pracą socjalną. Doprowadziło to do przeniesienia do Niemiec pionierskich rozwiązań wypracowanych w tej dziedzinie przez J. Addams ${ }^{40}$. Istotną rolę odgrywały także wyjazdy kobiet na studia, czy poszukiwanie przez nie pracy za granicą, jak również polityczne banicje działaczek widoczne chociażby na przykładzie ziem polskich (np. postać Marii Szeligi). Badania nad transnarodowym zsieciowaniem działaczek podkreślają kluczowe znaczenie umiejętności władania przez nie obcymi językami, zwłaszcza angielskim, niemieckim i francuskim, które przez Międzynarodową Radę Kobiet stawiane były na równi jako języki kongresowe. Podkreśla się także rolę uwarunkowań religijnych, gdyż działaczkami aktywnymi w międzynarodowym ruchu kobiecym były zazwyczaj wykształcone kobiety pochodzenia mieszczańskiego i wyznania protestanckiego, a do tego niezależne finansowo lub znane i dzięki temu mogące liczyć na możliwość znalezienia instytucji lub osób prywatnych mogących opłacić koszty podróży ${ }^{41}$.

Badania nad ruchem kobiecym w Niemczech wskazują, że transferowany wieloma kanałami program międzynarodowego ruchu kobiecego stanowił dla miejscowych stowarzyszeń i aktywistek impuls do działań i organizowania się. Inspirował, ale też do definiowania na nowo kwestii, które pozornie miały charakter lokalny, a w transnarodowym kontekście nabierały innego znaczenia. Był więc wskazówką jak działać, jednak zawsze z uwzględnieniem przede wszystkim priorytetów narodowych i metodami dostosowywanymi do sytuacji politycznej w danym kraju i zakresu społecznego poparcia dążeń emancypacyjnych kobiet ${ }^{42}$.

Rozwinięta i zinstytucjonalizowana $\mathrm{w}$ formule kongresu transnarodowa sieć działaczek kobiecych na przełomie XIX i XX w., z centrum jakim stanowiła Międzynarodowa Rada Kobiet doprowadziła niemiecką badaczkę Karen Offen do stwierdzenia, że nie odbiegała ona od współczesnych transnarodowych sieci feministycznych, które irańsko-amerykańska

$40 \quad$ Zob.: A. Schüler, Frauenbewegung und soziale Reform. Jane Addams und Alice Salomon im transantlantischen Dialog 1880-1933, Franz Steiner Verlag, Stuttgart 2004.

$41 \quad$ L. Klejman, Les Congrès..., s. 80-81. W niektórych kongresach (Paryż 1900 r.) uczestniczyły również kobiety wywodzące się ze środowisk robotniczych, jednak bariery stanowe (klasowe) uniemożliwiały im porozumienie z przedstawicielkami mieszczaństwa. J. Evans, The Feminists..., s. 52; L.J. Rupp, Zur Organisationsgeschichte der internationalen..., s. 5.

42 U. Gerhard, National oder International..., s. 37. 
socjolożka Valentine Moghadam definiuje jako struktury zorganizowane powyżej poziomu państwa, mające na celu jednoczenie kobiet $\mathrm{z}$ różnych państw wokół wspólnego programu ${ }^{43}$.

\section{Podsumowanie}

Podsumowując, kongresy działaczek kobiecych były wyrazem dojrzałości transnarodowej sieci aktywistek, które dążąc do rozwiązania kwestii kobiecej na początku II połowy XIX w. zaczęły poszukiwać nowych narzędzi mających zjednać opinię publiczną i elity rządzące do wymagających zazwyczaj drogi prawnej zmian statusu kobiet. Nadanie kongresom charakteru międzynarodowego miało służyć ukazaniu kwestii kobiecej jako istotnego problemu wymagającego rozwiązania. Początkowo kongresy tylko z nazwy miały taki charakter. Dopiero te, które współorganizowała założona w 1888 r. Międzynarodowa Rada Kobiet w rzeczywistości zbierały działaczki z szeregu państw należących do zachodniego kręgu cywilizacyjnego. Sprzyjała temu nie tylko organizacja Rady oparta na kryterium narodowym (de facto państwowym), ale także jej umiarkowany program, który skrystalizował się ostatecznie podczas obrad kongresu w Londynie w 1899 r. Program ten, chociaż mało klarowny, posiadał jedną ważną cechę, mianowicie dystansował się od wszelkich kontrowersyjnych kwestii, a przez to sprzyjał rozbudowie transnarodowych powiązań między działaczkami, których zdecydowana większość nie popierała hasła równouprawnienia, szermowanego podczas pierwszych, organizowanych w Paryżu od 1878 r. międzynarodowych kongresów praw kobiet. Nie odnosiły one więc zamierzonych rezultatów, wywołując zamiast uznania raczej oburzenie opinii publicznej i ironiczne komentarze dyskredytujące działaczki. Duże zainteresowanie kongresami Międzynarodowej Rady Kobiet sprzyjało też uruchomieniu nowych kanałów transferowania treści wypracowanych podczas obrad i wzmacniało oddziaływanie przez prasę, publikacje pokongresowe oraz działalność upowszechniającą tzw. wędrownych aktywistek. W ten sposób budowała się wielopunktowa zbieżność programowa mieszczańskiego ruchu kobiecego rozwijającego się w poszczególnych państwach i tym samym przekonanie o istnieniu jednej, ponadnarodowej kwestii kobiecej.

$43 \quad$ K. Offen, Understanding International Feminisms..., s. 27-28. 


\section{Bibliografia}

\section{Źródła}

Bäumer G., Die Geschichte der Frauenbewegung in Deutschland, [w:] H. Lange, G. Bäumer (red.), Handbuch der Frauenbewegung in den Kulturländern, Berlin 1901.

Chwatowa (Poland) Mne de, The Teaching of the Rudiments of Law in Primary Schools, [w:] the Countess of Aberdeen (red.), The International Congress of Women of 1899: Women in Politics being the Political Section of the International Congress of Women, London, July 1899, London 1900.

Gordon O., The Formation and Growth of the International Council of Women,

[w:] Agenda for the Quinquennial Sessions of the International Council of Women, held at Toronto, Canada, June 1909, 1909.

International Council of Women. Quinquennial Reunion in Canada 1909, 1910.

International Council of Women. Report on the Quinquennial Meetings, Rome 1914. J.M., Die Tagung des Weltbunder für Frauentimmrecht, „Frauenbestrebungen. Offizielles Organ der „Union für Frauenbestrebungen“ 1906, nr 10.

Kongres kobiecy, „Postęp” 1896, nr 219.

Oresko E., Poland, [w:] Stanton T. (red.), The Woman Question in Europe. A Series of Original Essays, London 1884.

Popelin M., Actes du Congrès Féministe International de Bruxelles 1912, 18921912, Bruxelles 1912.

Report on the quinquennial meetings. Rapport de lassemblée quinquennal. Bericht über die Generalversammlung, Rome 1914.

W.W. [Wojnarowska], Francusko-międzynarodowy kongres kobiecy, „Głos. Tygodnik Literacko-Społeczno-Polityczny" 1889, nr 29.

\section{Opracowania}

Anderson B.S., Joyous Greetings: The First International Women's Movement, 18301860, University Press, Oxford 2000.

Berkovitch N., From Motherhood to Citizenship. Women's Rights and International Organizations, The Johns Hopkins University Press, Baltimore-London 1999. Blobaum R., „Kwestia kobieca” w Królestwie Polskim (1900-1914), [w:] A. Janiak-Jasińska, K. Sierakowska, A. Szwarc (red.), Działaczki społeczne, feministki, obywatelki. Samoorganizowanie się kobiet na ziemiach polskich do 1918 roku (na tle porównawczym), Wydawnictwo Neriton, Warszawa 2008.

Carlier J., A Forgotten Instance of Women's International Organising. The Transnational Feminist Networks of the Women's Progressive Society (1890) and the International Women's Union (1893-1898), [w:] O. Janz, D. Schönpflug (red.), Gender History in a Transnational Perspective: Networks, Biographies, Gender Orders, Berghahn Books, New York - Oxford 2014. 
Dudeková G., Międzynarodowa działalność kobiet w Austro-Węgrzech i VII Kongres Międzynarodowego Stowarzyszenia na Rzecz Praw Wyborczych Kobiet w Budapeszcie w 1913 roku, [w:] A. Janiak-Jasińska, K. Sierakowska, A. Szwarc (red.), Działaczki społeczne, feministki, obywatelki. Samoorganizowanie się kobiet na ziemiach polskich do 1918 roku (na tle porównawczym), Wydawnictwo Neriton, Warszawa 2008.

Evans J., The Feminists: Women's Emancipation Movements in Europe, America and Australasia 1840-1920, Routledge, London - New York 2013.

Gehmacher J., Moderne Frauen, die Neue Welt und der alte Kontinent. Käthe Schirmacher reist im Netzwerk der Frauenbewegung, „Österreichische Zeitschrift für Geschichtswissenschaften” 2011, t. 22, nr 1.

Gehmacher J., Reisende in Sachen Frauenbewegung Käthe Schirmacher zwischen Internationalismus und nationaler Identifikation, „Ariadne. Forum für Frauen- und Geschlechtergeschichte" 2011, t. 60.

Gehring M., Vorbild, Inspiration oder Abgrenzung? Die Amerikarezeption in der deutschen Frauenbewegug im 19 Jahrhundert, Campus Verlag, Frankfurt New York 2020.

Gerhard U., National oder International. Die internationalen Beziehungen der deutschen bürgerlichen Frauenbewegung, „Feministische Studien” 1994, nr 2.

Janz O., Schönpflug D., Introduction, [w:] O. Janz, D. Schönpflug (red.), Gender History in a Transnational Perspective: Networks, Biographies, Gender Orders, Berghahn Books, New York - Oxford 2014.

Kaelble H., Kirsch M., Schmidt-Gernig A., Zur Entwicklung transnationaler Öffentlichkeiten und Identitäten im 20. Jahrhundert. Eine Einleitung, [w:] H. Kaelble, M. Kirsch, A. Schmidt-Gernig (red.), Transnationale Öffentlichkeiten und Identitäten im 20. Jahrhundert, Campus Verlag, Frankfurt - NewYork 2002.

Kern K.L., „The Cornerstone of a New Civilization“. The First International Council of Women and the Campaign for "Social Purity”, „Kentucky Law Journal” 1996, t. 84, nr 4.

Kinnebrock S., „Wahrhaft international?" Soziale Bewegungen zwischen nationalen Öffentlichkeiten und internationalem Bewegungsverband, [w:] E. Schöck-Quinteros, A. Schüler, A. Wilmers, K. Wolff (red.), Politische Netzwerkerinnen. Internationale Zusammenarbeit von Frauen 1830-1960, Trafo Verlag, Berlin 2017.

Klausmann Ch., Schäfer R., Schüller E., Wischermann U., Internationale Kongresse der alten und neuen Frauenbewegung, „Feministische Studien” 1994, nr 2.

Klejman L., Les Congrès féministes internationaux, „Mil neuf cent: Revue d histoire intellectuelle (ex-Cahiers Georges Sorel)" 1989, nr 7.

Leszczawski-Schwerk A., „Die umkämpfende Tore zur Gleichberechtigung” - Frauenbewegungen in Galizien (1867-1918), Lit, Münster 2015. 
Offen K., Debating the Woman Question in the French Third Republic, 1879-1920, University Press, Cambridge 2018.

Offen K., European Feminism 1700-1950. A Political History, University Press, Stanford 2000.

Offen K., Overcoming Hierarchies Through Internationalism. May Wright Sewall's Engagement with the International Council of Women (1888-1904), [w:] F. de Haan, M. Allen, J. Purvis, K. Daskalova (red.), Women's Activism. Global Perspectives from the 1890s to the Present, Routledge, London - New York 2013.

Offen K., Understanding International Feminisms as 'Transnational' - an Anachronism? May Wright Sewall and the Creation of the International Council of Women, 1889-1904 [w:] O. Janz, D. Schönpflug (red.), Gender History in a Transnational Perspective: Networks, Biographies, Gender Orders, Berghahn Books, New York - Oxford 2014.

Rasmussen A., Les Congrès internationaux liés aux Expositions universelles de Paris (1867-1900), „Mil neuf cent: Revue d histoire intellectuelle (ex-Cahiers Georges Sorel)" 1989, nr 7.

Rupp L.J., Worlds of Women: The Making of an International Women's Movement, Princeton University Press, Princeton 1997.

Rupp L.J., Zur Organisationsgeschichte der internationalen Frauenbewegung vor dem Zweiten Weltkrieg, „Feministische Studien” 1994, nr 2.

Sangster J., Crossing Boundaries: Women's Organizing in Europe and the Americas, 1880s-1940s, [w:] P. Jonsson, S. Neunsinger, J. Sangster (red.), Crossing Boundaries: Women's Organizing in Europe and the Americas, 1880s-1940s, Uppsala Universitet, Uppsala 2007.

Schötz S., Jenseits von Grenzen. Transnationale Kommunikation und transnationale Akteutinnen im Umfeld des Allgemeinen Deutschen Frauenvereins, [w:] E. Schöck-Quinteros, A. Schüler, A. Wilmers, K. Wolff (red.), Politische Netzwerkerinnen. Internationale Zusammenarbeit von Frauen 1830-1960, Trafo Verlag, Berlin 2017.

Schüler A., Frauenbewegung und soziale Reform. Jane Addams und Alice Salomon im transantlantischen Dialog 1880-1933, Franz Steiner Verlag, Stuttgart 2004.

Schüler A., Wolff K., „Es sind die gleichen Überzeugungen, die die Frauen aller Länder erfüllen..." Zur Entstehung von internationalen Netzwerken in den Frauenbewegung, [w:] E. Schöck-Quinteros, A. Schüler, A. Wilmers, K. Wolff (red.), Politische Netzwerkerinnen. Internationale Zusammenarbeit von Frauen 18301960, Trafo Verlag, Berlin 2017.

Wikander U., Equality Claimed: Women's Congresses in Paris 1892 \& 1896 , http:// www.ullawikander.se/wp-content/uploads/2017/04/Chapter-6-Pdf.pdf [dostęp: 25.08.2020]. 
Wikander U., Some "Kept the Flag” of Feminist Demands Waving. Debates at International Congresses on Protecting Women Workers, [w:] U. Wikander, A. Kessler-Harris, J.E. Lewis (red.), Protecting Women. Labor Legislation in Europe, the United States, and Australia, 1880-1920, University of Illinois, Urbana 1995.

Wikander U., Suffrage and the Labour Market: European Women at International Congresses in London and Berlin, 1899 and 1904, [w:] P. Jonsson, S. Neunsinger, J. Sangster (red.), Crossing Boundaries: Women's Organizing in Europe and the Americas, 1880s-1940s, Uppsala Universitet, Uppsala 2007.

Wilkins W.H., The Paris International Feminist Congress of 1896 and its French Antecedents, „North Dakota Quarterly” 1975, nr 4 (Autumn).

Zimmermann S., Frauenbewegungen, Transfer und Trans-Nationalität. Feministisches Denken und Streben im globalen und zentralosteuropäischen Kontext des 19. und frühen 20. Jahrhunderts, [w:] H. Kaelble, M. Kirsch, A. Schmidt-Gernig (red.), Transnationale Öffentlichkeiten und Identitäten im 20. Jahrhundert, Campus Verlag, Frankfurt - NewYork 2002. 